\title{
Unionid Mussels from Nearshore Zones of Lake Erie
}

Todd D. Crail

University of Toledo, todd.crail@utoledo.edu

Robert A. Krebs

Cleveland State University, r.krebs@csuohio.edu

David T. Zanatta

Central Michigan University, zanat1d@cmich.edu

Follow this and additional works at: https://engagedscholarship.csuohio.edu/scibges_facpub

Part of the Biology Commons

How does access to this work benefit you? Let us know!

Publisher's Statement

NOTICE: this is the author's version of a work that was accepted for publication in Journal of Great Lakes Research. Changes resulting from the publishing process, such as peer review, editing, corrections, structural formatting, and other quality control mechanisms may not be reflected in this document. Changes may have been made to this work since it was submitted for publication. A definitive version was subsequently published in Journal of Great Lakes Research, 37, 1, (March 2011) DOI 10.1016/j.jglr.2010.12.006

\section{Recommended Citation}

Crail TD, Krebs RA, Zanatta DT. 2011. Unionid mussels from nearshore zones of lake erie. J Great Lakes Res 37(1):199-202.

This Article is brought to you for free and open access by the Biological, Geological, and Environmental Sciences Department at EngagedScholarship@CSU. It has been accepted for inclusion in Biological, Geological, and Environmental Faculty Publications by an authorized administrator of EngagedScholarship@CSU. For more information, please contact library.es@csuohio.edu. 


\title{
Unionid mussels from nearshore zones of Lake Erie
}

\author{
Todd D. Crail ${ }^{\mathrm{a}, *}$, Robert A. Krebs ${ }^{\mathrm{b}}$, David T. Zanatta ${ }^{\mathrm{c}}$ \\ a Department of Environmental Sciences, University of Toledo, $\mathrm{OH}$, USA \\ ${ }^{b}$ Department of Biological, Geological, and Environmental Sciences, Cleveland State University, Cleveland, OH, USA \\ ' Department of Biology, Central Michigan University, Mount Pleasant, MI, USA
}

\section{Introduction}

Upon invading the productive lakes Erie and St. Clair, Eurasian dreissenid mussels (Bivalvia: Dressenidae) killed off many native unionid mussels (Bivalvia: Unionidae) by fouling (Ricciardi et al., 1998) and out-competing the native species for food (Parker et al., 1998; Baker and Levinton, 2003). This process began soon after their detection in 1986 (Herbert et al., 1989; Schloesser and Nalepa, 1994), although prior to the introduction of dreissenids, unionid mussel communities were evidently already declining in diversity and abundance across the region (Nalepa and Gauvin, 1988; Nalepa et al., 1991; Metcalfe-Smith et al., 1998; Krebs et al., 2010).

Following the dreissenid introduction, a number of studies documented the progressive loss of local populations of unionids in the Great Lakes (Schloesser and Nalepa, 1994; Gillis and Mackie, 1994; Nalepa et al., 1996; Ecological Specialists, 1999) and connecting rivers (Ricciardi et al., 1996; Schloesser et al., 2006), but several coastal marsh refuges were identified in Lake Erie. The best documented are Metzger's Marsh (Nichols and Wilcox, 1997; Nichols and Amberg, 1999), Crane Creek at the Ottawa National Wildlife Refuge (Bowers and de Szalay, 2004 and others) and Thompson Bay

* Corresponding author. Department of Environmental Sciences, MS 604, University of Toledo, Toledo, Ohio, USA 43606.

E-mail addresses: todd.crail@utoledo.edu (T.D. Crail), R.KREBS@csuohio.edu (R.A. Krebs), zanat1d@cmich.edu (D.T.Zanatta).
(Presque Isle, PA; Schloesser and Mateller, 1999). Nearshore refuges also were identified in the St. Clair River delta of Lake St. Clair (Zanatta et al., 2002; McGoldrick et al., 2009) and along the Michigan coast of Lake Erie (Schloesser et al., 1997; Shackelford et al., 2009). The hope was that these refuges in combination with unimpacted riverine refuges could someday provide brood stock for colonizing a wider range of lake environments should the influence of dreissenids decline.

Two major impediments to locating native mussels in large, productive lakes are water clarity and depth. For example, $95 \%$ of visible light is attenuated within a depth of $1.5 \mathrm{~m}$ in Maumee Bay and other nearshore sites in the southwestern end of Lake Erie (Bridgeman and Pennamon, 2010). Given such limitations, we performed preliminary surveys of Lake Erie's extant unionid fauna by two approaches. The first took advantage of naturally occurring low pressure, west windgenerated seiches that create periodic low water levels. The amount of water displaced can be substantial: a seiche dropped water levels $1.6 \mathrm{~m}$ (64 in.) below the low water mark on December 10, 2009 (Lake Erie water level gauging station at Toledo; U.S. National Oceanographic and Atmospheric Administration, 2010). However, such searches are largely limited to the western edges of Lake Erie and Sandusky Bay. A second approach was extensive beach and shallow nearshore surveys. We focused on identifying fresh dead and/or live mussels washed up after storms in areas where public access was low. Using these surveying methods, we found a surprising number of unionids (both individuals and species), and wish to discuss our results to create awareness that this native fauna may be found in areas of the lake beyond the documented refuges. 


\section{Methods}

We surveyed the nearshore (within $500 \mathrm{~m}$ of the bank) for live unionids after natural seiches occurred on five different occasions (Fig. 1). Search methods varied in each seiche survey based on available time before water returned and type of substrate, as soft mud restricted movement: November 29, 2007 at Bayshore Road, Lucas County, $\mathrm{OH}$ (20-min timed search, one searcher) and Winous Point, Ottawa County, within Sandusky Bay (20-min timed search, one searcher); September 10, 2008, at Bayshore Road and Maumee Bay State Park (small seiche, search limited to $30 \mathrm{~min}$ in the wave zone at each location, one searcher), Lucas County, OH; September 28, 2009, Bayshore Road and Maumee Bay State Park (30-min timed search, one searcher); September 29, 2009 at Luna Pier, Monroe County, MI (60-min timed search, two searchers). On December 10, 2009, we again sampled at Bayshore Road, however this time we estimated mussel density. Four random $100 \mathrm{~m}^{2}$ quadrat sites were surveyed by sight during this seiche. Location was determined by throwing a meter stick and creating a $10 \times 10 \mathrm{~m}$ perimeter using the center of the stick as the centroid for the quadrat. All individuals were found by sight or touch, collected, measured and returned. Substrate consisted of shell (Corbicula fluminea and Dreissena sp.) and sand, coated by fine muck. No attempt was made to quantify the contribution of substrate sizes within the samples.

Beach and estuary surveys were conducted at numerous sites between 2004 and 2009 (Fig. 1). In each case, searches covered all accessible waterfront areas and shallow inlets and marshes adjacent the lake. As the focus was a qualitative assessment of the evidence for mussels, no attempt was made to restrict search times or to make them uniform across substrates and shoreline environment of very different character. Basically, a maximum available effort was applied at each site to find live mussels and recently spent shells.

\section{Results}

We identified 16 unionid species still living in or near Lake Erie, including sites in the western and the central basins (Table 1). At six sites live unionid mussels occurred in the lake (Fig. 1): Luna Pier, Bayshore, Maumee Bay, Crane Creek shoreline, East Harbor State Park, and Winous Point in Sandusky Bay. Each of these observations consisted of live individuals from two to eight species, some of which are Ohio and Michigan state-listed species: Obliquaria reflexa, Uniomerus tetralasmus, Truncilla donaciformis, and Truncilla truncata occurred at multiple sites, and one live individual of Ligumia nasuta (state endangered) was found at the Bayshore Site. The most common species were Leptodea fragilis and Pyganodon grandis, both of which occurred at most sites. Numerous species were found only in weathered condition (degraded periostracum and nacre, partial shell pieces, etc.), and these were not recorded.

More live individuals were observed following seiche events. For example, at the Bayshore site in 2007, we found 34 individuals representing three species in our 20-min timed search. Most were $L$. fragilis $(N=28$, mean shell length $74 \pm 18.5 \mathrm{~mm} \mathrm{SD})$ with individuals as small as $29 \mathrm{~mm}$. Rates of Dreissena infection were less than ten per individual, except for a $109 \mathrm{~mm}$ L. fragilis with 19 Dreissena attached. During the smaller events at Bayshore in 2008, we recovered 32 individuals again dominated by $L$. fragilis (mean shell length was $55 \pm$ $19.9 \mathrm{~mm}$ SD). At Maumee Bay State Park the same day, $18 \mathrm{~L}$. fragilis were found (mean shell length was $38 \pm 24.4 \mathrm{~mm} \mathrm{SD}$ ) and the smallest individual was $16 \mathrm{~mm}$. All individuals recovered were clear of Dreissena. Beach surveys at Cedar Point (Fig. 1) produced a similar number of $L$. fragilis shells that averaged $71 \mathrm{~mm}(N=33)$ and $P$. grandis shells of $76 \mathrm{~mm}(N=5)$; growth lines suggested an age of no more than three for most individuals. By contrast, one old $L$. fragilis shell from the Old Woman Creek estuary was $154 \mathrm{~mm}$ long, and most $P$. grandis from this estuary fell in the $130-140 \mathrm{~mm}$ size range. Density of mussels was estimated only once. Applying four random $100 \mathrm{~m}^{2}$ quadrats sites at a Bayshore seiche (December 10, 2009), we collected three species, L. fragilis, P. grandis, and Amblema plicata-in order of decreasing abundance, with a mean overall density of 0.09 unionids/ $\mathrm{m}^{2}(N=36$ or $9 \pm 3.6$ per quadrat $)$.

\section{Discussion}

Native freshwater mussels (Unionidae) live in Lake Erie despite abundant dreissenid populations. $L$. fragilis and $P$. grandis appear to be common in some nearshore zones based either on live animals found during seiches or on numerous fresh shells washed up along the shore. Both native species are thin shelled, fast growing mussels, and their presence is consistent with past findings, as L. fragilis has

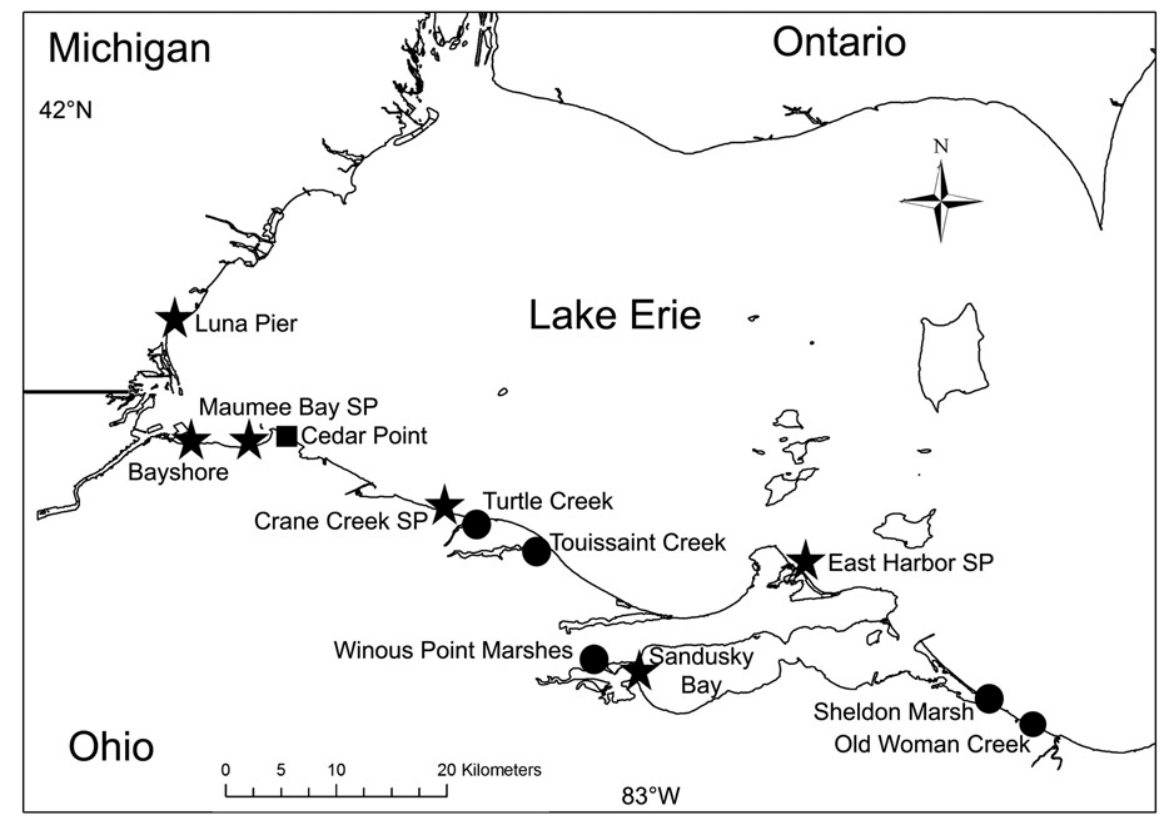

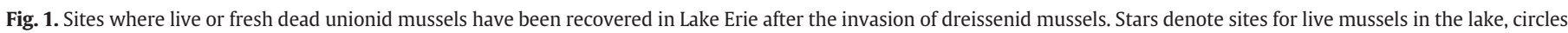
denote sites for live mussels in marshes, and squares denote sites where only fresh dead shell has been collected. 
Table 1

Observed Unionid species found along western Lake Erie beaches and surrounding estuaries and marshes during 2007-2009. L= Live, FD = Fresh Dead.

\begin{tabular}{|c|c|c|c|c|c|c|c|c|c|c|c|c|}
\hline Mussel species & $\begin{array}{l}\text { Luna } \\
\text { Pier }\end{array}$ & Bayshore & $\begin{array}{l}\text { Maumee } \\
\text { Bay SP }\end{array}$ & $\begin{array}{l}\text { Cedar } \\
\text { Point }\end{array}$ & $\begin{array}{l}\text { Crane } \\
\text { Creek SP }\end{array}$ & $\begin{array}{l}\text { Turtle } \\
\text { Creek }\end{array}$ & $\begin{array}{l}\text { Toussaint } \\
\text { Creek }\end{array}$ & $\begin{array}{l}\text { Winous Point } \\
\text { Marsh }\end{array}$ & $\begin{array}{l}\text { Sandusky Bay } \\
\text { at Winous }\end{array}$ & $\begin{array}{l}\text { East } \\
\text { Harbor SP }\end{array}$ & $\begin{array}{l}\text { Sheldon } \\
\text { Marsh }\end{array}$ & $\begin{array}{l}\text { Old Woman } \\
\text { Creek }\end{array}$ \\
\hline Amblema plicata & FD & $\mathrm{L}$ & FD & & $\mathrm{L}$ & & $\mathrm{L}$ & & FD & & & \\
\hline Anodontoides ferussacianus ${ }^{\mathrm{a}}$ & & & & & & & & & & & $\mathrm{L}$ & \\
\hline Lasmigona complanata & & $\mathrm{L}$ & & & & & $\mathrm{L}$ & & $\mathrm{L}$ & $\mathrm{L}$ & & \\
\hline Lampsilis siliquoidea & & $\mathrm{L}$ & FD & & & & & & & & & \\
\hline Leptodea fragilis & $\mathrm{L}$ & $\mathrm{L}$ & $\mathrm{L}$ & FD & $\mathrm{L}$ & & $\mathrm{L}$ & & $\mathrm{L}$ & $\mathrm{L}$ & $\mathrm{L}$ & $\mathrm{L}$ \\
\hline Ligumia nasuta & & $\mathrm{L}$ & & & & & & & & & & \\
\hline Obliquaria reflexa & & FD & FD & & & & & & FD & & & \\
\hline Potamilus alatus & & $\mathrm{L}$ & $\mathrm{L}$ & & & & $\mathrm{L}$ & & $\mathrm{L}$ & $\mathrm{L}$ & & \\
\hline Pyganodon grandis & $\mathrm{L}$ & $\mathrm{L}$ & $\mathrm{L}$ & FD & $\mathrm{L}$ & $\mathrm{L}$ & $\mathrm{L}$ & $\mathrm{L}$ & $\mathrm{L}$ & $\mathrm{L}$ & $\mathrm{L}$ & $\mathrm{L}$ \\
\hline Quadrula quadrula & & & FD & & $\mathrm{L}$ & & $\mathrm{L}$ & & FD & & & $\mathrm{L}$ \\
\hline Quadrula pustulosa & & FD & FD & & FD & & & & $\mathrm{FD}$ & & & \\
\hline Toxolasma parvum & & FD & & & & & $\mathrm{L}$ & $\mathrm{L}$ & $\mathrm{L}$ & & & $\mathrm{FD}$ \\
\hline Truncilla truncata & & $\mathrm{L}$ & FD & & & & & & & & & \\
\hline Truncilla donaciformis & FD & & & & & & & & & & & \\
\hline Uniomerus tetralasmus $\mathrm{s}^{\mathrm{a}}$ & & & & & FD & $\mathrm{L}$ & & $\mathrm{L}$ & & & & $\mathrm{L}$ \\
\hline Utterbackia imbecillis ${ }^{\mathrm{a}}$ & & & & & & $\mathrm{L}$ & $\mathrm{L}$ & $\mathrm{L}$ & $\mathrm{L}$ & & $\mathrm{L}$ & $\mathrm{L}$ \\
\hline
\end{tabular}

a Not found in the lake, occurrence in estuaries and marshes only.

demonstrated resilience against dreissenid infestation in Metzger Marsh (Nichols and Amberg, 1999). However, evidence of 14 other species also suggests that the unionid communities of Lake Erie may be diverse even if in low abundance.

The question is whether these communities are self-sustaining in the presence of the dreissenid mussels. Recovery of multiple age classes (based on variable size and many small individuals) suggests recruitment occurs at least for $L$. fragilis, $P$. grandis, A. plicata and Potamilus alatus. While lacking quantitative density data beyond the Bayshore site ( 0.09 unionids $\left./ \mathrm{m}^{2}\right)$, our qualitative observations suggest that densities among other sites are similar and consistent with reported densities of $0.03-0.12$ unionids $/ \mathrm{m}^{2}$ in the St. Clair Delta (McGoldrick et al., 2009).

Some of our observations also suggest processes for the persistence/ return of unionids in the nearshore. Bowers and De Szalay (2004) found that abundances of dreissenids fouling unionids were extremely limited at shallower depths of Crane Creek. Unionids retained byssal threads of dreissenids that had at one point colonized the animal but were subsequently lost. They suggest that fluctuating water levels stress dreissenids more than unionids, and McMahon (1996) found that exposure to freezing conditions can kill dreissenids. Abundances of dreissenids on rocks and logs declined following seiches when freezing occurred (TC, unpublished data). Under such circumstances, shallowwater debris may become devoid of dreissenids until spawning occurs the following year. Furthermore, dreissenids in shallow water are more vulnerable to predation from waterfowl (Werner et al., 2005), as well as predation by Orconectes crayfish (Perry et al., 1997), turtles (Serrouya et al., 1995; Patterson and Lindeman, 2009) and a variety of fish (French and Love, 1995; Tucker et al., 1996; Molloy et al., 1997; Thorp et al., 1998; Magoulick and Lewis, 2002; Pothoven and Nalepa, 2006; Bowers and de Szalay, 2007).

The question now is what are the origins of the unionids we observed? Do they represent recovering/expanding populations or dispersal from coastal wetlands and tributaries? The similarity between the present low-density nearshore fauna and historical deepwater fauna (Woods, 1953) may suggest present populations could be expanding from remnant communities in deeper water. In a pre-dreissenid study of mussels in the western basin, Woods (1953) collected live specimens of just 13 species; although his literature review documented that 27 species should be common and 8 others rare within the lake. He partitioned each species into two groups, those inhabiting the shallow nearshore (0-5 $\mathrm{m}$ depth) and those inhabiting the deeper water $(>5 \mathrm{~m})$. Fifteen of the sixteen species we found (Table 1$)$, Woods (1953) described as deep-water species with one exception. The sixteenth, Quadrula quadrula, occurs in shallow river estuaries (Krebs et al., 2010). Considering the much lower presence of fresh shells found in an extensive survey of Lake Erie's western basin in 1998 (Ecological Specialists, 1999) paired with the live individuals of 15 of the 16 species (the exception was L. nasuta) found in unpublished surveys by T. Crail in the lower reaches of the Maumee, Portage and Sandusky Rivers, determination of the source will likely require investigation of the genetic structure of populations.

A final issue for unionid populations in the region is their connectivity. While dreissenid mussels have much less impact on most native mussel populations in rivers (Great Lakes tributaries), these populations remain isolated (Krebs et al., 2010), and therefore likely possess genetic differences among the populations inhabiting even neighboring streams (Krebs, 2004; Zanatta et al., 2007; Zanatta and Murphy, 2008). Likewise, native mussel populations in the coastal areas may now be small and isolated given the rapid decline in numbers. Connection to larger healthy populations often helps sustain natural populations without management (Jones et al., 2006). Additional research is needed to elucidate the historical genetic structure of unionid populations in the Great Lakes watershed, which may reveal source-sink dynamics of communities (i.e., tributary river source vs. deep water lake source) in the region.

Although limited in the areas surveyed, our observations from seiches and beach surveys highlight that mussel occurrence in Lake Erie is not isolated to specific habitats. Massive amounts of spent Dreissena spp. shell are now fortifying substrates, which may help unionids occupy depositional soft substrates due to intensive agricultural land use (Richards et al., 2008), particularly in low energy sections of Maumee Bay and Sandusky Bay, a phenomenon also considered by others (e.g., Burlakova et al., 2000; Karatayev et al., 2002; Strayer and Malcom, 2006; Sousa et al., 2009). In Maumee Bay, the benthic environments have also been sediment-starved of coarse particles due to upstream dams and dredging and have downcut into hardpan glacial lake-derived lacustrine clays (Fuller, 2002). The bulk addition of shell fragments is creating coarse sediments that may now be deep enough for unionids to anchor infaunally themselves (Schloesser et al., 1997). Regardless of the mechanism for their contemporary presence, Lake Erie remains a system in flux (Strayer and Malcom, 2007), and a greater priority should be placed on understanding the ecological processes that affect the success and failure of this important native mussel fauna in this ecosystem.

\section{Acknowledgements}

Student stipend support to TC by a fellowship from the NSF GK-12 program \# 0742395 "Graduate Fellows in High School STEM Education: An Environmental Science Learning Community at the Land-Lake Ecosystem Interface" through the Lake Erie Research 
Center. The Winous Point Marsh Conservancy is also acknowledged along with a small grant to RK from the Cleveland Zoo. We would like to thank Tim Herman of The Toledo Zoo for bringing the population at the Bayshore site to our attention, Maria Herman and Philip Mathias for their help in the field during seiche events and the associated adverse winter weather conditions, Jeff Pallotta and Paul Doerder for their assistance in marsh surveys and beach combing, and Hans Gottgens for thoughtful feedback. This is contribution 2011-02 from the Lake Erie Center.

\section{References}

Baker, S.M., Levinton, J.S., 2003. Selective feeding by three native North American freshwater mussels implies food competition with zebra mussels. Hydrobiologia 505, 97-105.

Bowers, R.W., de Szalay, F.A., 2004. Effects of hydrology on unionids (Unionidae) and zebra mussels (Dreissenidae) in a Lake Erie coastal wetland. Am. Midl. Nat. 151, 286-300.

Bowers, R.W., de Szalay, F.A., 2007. Fish predation of zebra mussels attached to Quadrula quadrula (Bivalvia: Unionidae) and benthic mollusks in a Great Lakes coastal wetland. Wetlands 27, 203-208.

Bridgeman, T.B., Pennamon, W.A., 2010. Lyngbya wollei in western Lake Erie. J. Great Lakes Res. 36, 167-171.

Burlakova, L.E., Karatayev, A.Y., Padilla, D.K., 2000. The impact of Dreissena polypmorpha (Pallas) invasion on unionid bivalves. Int. Rev. Hydrobiol. 85, 529-541.

Ecological Specialists, Inc., 1999. Final report: Unionid survey in the western basin of Lake Erie near the Bass Islands and southwest shore. 98-015. Ohio Division of Wildlife, Department of Natural Resources, Columbus, $\mathrm{OH}$.

French, J.R.P., Love, J.G., 1995. Size limitation on zebra mussels consumed by freshwater drum may preclude the effectiveness of drum as a biological controller. J. Freshw. Ecol. 10, 379-383.

Fuller, J.A., 2002. Bank recession and lakebed downcutting; response to changing water levels at Maumee Bay State Park, Ohio. J. Great Lakes Res. 28, 352-361.

Gillis, P.L., Mackie, G.L., 1994. Impact of the zebra mussel, Dreissena polymorpha, on populations of Unionidae (Bivalvia) in Lake St. Clair. Can. J. Zool. 72, 1260-1271.

Herbert, P.D., Muncaster, B.W., Mackie, G.L., 1989. Ecological and genetic studies on Dreissena polymorpha (Pallus): a new mollusc in the Great Lakes. Can. J. Fish. Aquat. Sci. 46, 1587-1591.

Jones, J.W., Hallerman, E.M., Neves, R.J., 2006. Genetic management guidelines for captive propagation of freshwater mussels (Unionoidea). J. Shellfish Res. 25, 527-535.

Karatayev, A.Y., Burlakova, L.E., Padilla, D.K., 2002. In: Leppakoski, E., et al. (Ed.), Invasive Aquatic Species of Europe. Kluwer Academic Publishers, Netherlands, pp. 433-446.

Krebs, R.A., 2004. Combining paternally and maternally inherited mitochondrial DNA for analysis of population structure in mussels. Mol. Ecol. 13, 1701-1705.

Krebs, R.A., Borden, W.C., Steiner, E.R., Lyons, M.S., Zawiski, W., Walton, B.M., 2010 Determinants of mussel diversity in Lake Erie tributaries. J. N. Am. Benthological Soc. $29,506-520$.

Magoulick, D.D., Lewis, L.C., 2002. Predation on exotic zebra mussels by native fishes: effects on predator and prey. Freshw. Biol. 47, 1908-1918.

McGoldrick, D.J., Metcalfe-Smith, J.L., Arts, M.T., Schloesser, D.W., Newton, T.J., Mackie, G.L., Monroe, E.M., Biberhofer, J., Johnson, K., 2009. Characteristics of a refuge for native freshwater mussels (Bivalvia: Unionidae) in Lake St. Clair. J. Great Lakes Res. 35, 137-146.

McMahon, R.F., 1996. The physiological ecology of the zebra mussel, Dreissena polymorpha, in North America and Europe. Am. Zool. 36, 339-363.

Metcalfe-Smith, J.L., Stanton, S.K., Mackie, G.L., Lane, N.M., 1998. Changes in the biodiversity of freshwater mussels in the Canadian waters of the lower Great Lakes drainage basin over the past 140 years. J. Great Lakes Res. 24, 845-858.

Molloy, D.P., Karatayev, A.Y., Burlakova, L.E., Kurandina, D.P., Laruelle, F., 1997. Natural enemies of zebra mussels: predators, parasites and ecological competitors. Rev. Fish. Sci. 5, 28-97.

Nalepa, T.F., Gauvin, J.M., 1988. Distribution, abundance, and biomass of freshwater mussels (Bivalvia: Unionidae) in Lake St. Clair. J. Great Lakes Res. 14, 411-419.

Nalepa, T.F., Manny, B.A., Roth, J.C., Mozley, S.C., Schloesser, D.W., 1991. Long-term decline in freshwater mussels (Bivalvia: Unionidae) of the western basin of Lake Erie. J. Great Lakes Res. 17, 214-219.

Nalepa, T.F., Hartson, D.J., Gostenik, G.W., Fanslow, D.L., Lang, G.A., 1996. Changes in the freshwater mussel community of Lake St. Clair: from Unionidae to Dreissena polymorpha in eight years. J. Great Lakes Res. 22, 354-369.

Nichols, S.J., Amberg, J., 1999. Co-existence of zebra mussels and freshwater unionids: population dynamics of Leptodea fragilis in a coastal wetland infested with zebra mussels. Can. J. Zool. 77, 423-432.
Nichols, S.J., Wilcox, D.A., 1997. Burrowing saves Lake Erie clams. Nature 389, 921.

Parker, B.C., Patterson, M.A., Neves, R.J., 1998. Feeding interactions between native freshwater mussels (Bivalvia: Unionidae) and zebra mussels (Dreissena polymorpha) in the Ohio River. Am. Malacological Bull. 14, 173-179.

Patterson, J.C., Lindeman, P.V., 2009. Effects of zebra and quagga mussel (Dreissena spp.) invasion on the feeding habits of Sternotherus oderatus on Presque Isle, northwestern Pennsylvania. Northeast. Nat. 16, 365-374.

Perry, W.L., Lodge, D.M., Lamberti, G.A., 1997. Impact of crayfish predation on exotic zebra mussels and native invertebrates in a lake-outlet stream. Can. J. Fish. Aquat. Sci. 54, 120-125.

Pothoven, S.A., Nalepa, T.F., 2006. Feeding ecology of lake whitefish in Lake Huron. J. Great Lakes Restor. 32, 489-501.

Ricciardi, A., Whoriskey, F.G., Rasmussen, J.B., 1996. Impact of the Dreissena invasion on native unionid bivalves in the upper St. Lawrence River. Can. J. Fish. Aquat. Sci. 53 $1434-1444$.

Ricciardi, A., Neves, R.J., Rasmussen, J.B., 1998. Impending extinctions of North American fresh-water mussels (Unionoida) following the zebra mussel (Dreissena polymorpha) invasion. J. Anim. Ecol. 67, 613-619.

Richards, R.P., Baker, D.B., Crumrine, J.P., Kramer, J.W., Ewing, D.E., Merryfield, B.J., 2008 Thirty-year trends in suspended sediment in seven Lake Erie tributaries. J. Environ. Qual. 37, 1894-1908.

Schloesser, D.W., Mateller, E.C., 1999. Mortality of unionid bivalves (Mollusca) associate with dreissenid mussels (Dreissena polymorpha and D. bugensis) in Presque Isle Bay, Lake Erie. Northeast. Nat. 6, 341-352.

Schloesser, D.W., Nalepa, T.F., 1994. Dramatic decline of unionid bivalves in offshore waters of western Lake Erie after infestation by the zebra mussel, Dreissena polymorpha. Can. J. Fish. Aquat. Sci. 51, 2234-2242.

Schloesser, D.W., Smithee, R.D., Longton, G.D., Kovalak, W.P., 1997. Zebra musse induced mortality of unionids in firm substrata of western Lake Erie and a habitat for survival. Am. Malacological Bull. 14, 67-74.

Schloesser, D.W., Kovalak, W.P., Longton, G.D., Ohnesorg, K.L., Smithee, R.D., 2006. Impact of zebra and quagga mussels (Dreissena spp.) on freshwater unionids (Bivalvia: Unionidae) in the Detroit River of the Great Lakes. Am. Midl. Nat. 140, 299-313.

Serrouya, R., Ricciardi, A., Whoriskey, F.G., 1995. Predation on zebra mussels (Dreissena polymorpha) by captive-reared map turtles (Graptemys geographica). Can. J. Zool 73, 2238-2243.

Shackelford, M.T., Longton, G.D., Bateman, J.D., Rachwal, J.C., Neruda, J.A., Kovalak, W.P. Schloesser, D.W., 2009. Distribution and Abundance of Native Mussels (Bivalvia: Unionidae) in a Thermal Discharge in Western Lake Erie. Abstracts of the 52nd Annual Conference on Great Lakes Research, May 18-22, Toledo, OH.

Sousa, R., Gutierrez, J.L., Aldridge, D.C., 2009. Non-indigenous invasive bivalves as ecosystem engineers. Biol. Invasions 11, 2367-2385.

Strayer, D.L., Malcom, H.M., 2006. Long-term demography of a zebra mussel (Dreissena polymorpha) population. Freshw. Biol. 51, 117-130.

Strayer, D.L., Malcom, H.M., 2007. Effects of zebra mussels (Dreissena polymorpha) on native bivalves: the beginning of the end or the end of the beginning? J. N. Am. Benthological Soc. 26, 111-122.

Thorp, J.H., DeLong, M.D., Casper, A.F., 1998. In situ experiments on predatory regulation of a bivalve mollusk (Dreissena polymorpha) in the Mississippi and Ohio Rivers. Freshw. Biol. 39, 649-661.

Tucker, J.K., Cronin, F.A., Soergel, D.W., 1996. Predation on zebra mussels (Dreissena polymorpha) by common carp (Cyprinus carpio). J. Freshw. Ecol. 11, 363-372.

U.S. National Oceanic and Atmospheric Administration, 2010. Historic Great Lakes Water Level and Meteorological Data available for Toledo Station 9063085 on the World Wide Web at http://tidesandcurrents.noaa.gov/data_menu.shtml?bdate= 20091208 \&edate $=20091211$ \&metinterval $=$ \&unit $=0$ \&shift $=$ g\&stn $=9063085+$ Toledo\%2C + OH\&type $=$ Meteorological + Observations\&format $=$ View + Plot AND http://tidesandcurrents.noaa.gov/data_menu.shtml?bdate $=20091208 \&$ eda te $=20091211 \&$ wl_sensor_hist $=W 1$ \&relative $=\&$ datum $=0 \&$ unit $=0 \&$ shift $=$ s\&stn $=9063085+$ Toledo\%2C + OH\&type $=$ Historic + Great + Lakes + Water + Level+Data\&format=View+Plot, Accessed June 30, 2010.

Werner, S., Mortl, M., Bauer, H.-G., Rothhaupt, K.-O., 2005. Strong impact of wintering waterbirds on zebra mussel (Dreissena polymorpha) populations at Lake Constance, Germany. Freshw. Biol. 50, 1412-1426.

Woods, K. G., 1953. Distribution and ecology of certain bottom-living invertebrates of the western basin of Lake Erie. Ph.D. Dissertation, The Ohio State University, Columbus, Ohio.

Zanatta, D.T., Murphy, R.W., 2008. The phylogeographic and management implications of genetic population structure in the imperiled snuffbox mussel, Epioblasma triquetra (Bivalvia: Unionidae). Biol. J. Linn. Soc. 93 371-38.

Zanatta, D.T., Mackie, G.L., Metcalfe-Smith, J.L., Woolnough, D.A., 2002. A refuge for native freshwater mussels (Bivalvia: Unionidae) from impacts of the exotic zebra mussel (Dreissena polymorpha) in Lake St. Clair. J. Great Lakes Res. 28, 479-489.

Zanatta, D.T., Fraley, S.J., Murphy, R.W., 2007. Population structure and mantle display polymorphisms in the wavy-rayed lampmussel, Lampsilis fasciola (Bivalvia: Unionidae). Can. J. Zool. 85, 1169-1181. 